\title{
Effects of warmer and drier climate conditions on plant composition and biomass production in a Mediterranean shrubland community
}

\author{
De Dato $\mathrm{G}^{(1)}$, Pellizzaro $\mathrm{G}^{(2)}$, Cesaraccio $C^{(2)}$, Sirca $C^{(3)}$, De Angelis P* \\ ${ }^{(1)}$, Duce $P^{(2)}$, Spano D ${ }^{(3)}$, Scarascia Mugnozza G ${ }^{(4)}$
}

Abstract: The last IPCC report predicts warmer and drier conditions for the future European climate and the Mediterranean basin could be highly sensible to future climatic change. In order to investigate how the forecast more stressing factors could affect Mediterranean shrubland ecosystems, an appropriate manipulation of the microclimate was carried out in an area covered by Mediterranean maquis aimed at extending the drought period and increasing the nighttime temperature. Soil cover, plant growth, litterfall, leaf water status, and leaf nutritional status were monitored over three growing seasons. The manipulation altered the microclimate according to common scenarios, increasing mean annual night-time air temperature by about $1{ }^{\circ} \mathrm{C}$ and mean annual temperature by about $0.5{ }^{\circ} \mathrm{C}$, and decreasing precipitation between $6-46 \%$ of the total rainfall during the growing seasons. A general increase of vegetation cover was observed in the whole community during the three years of experimentation. This positive temporal pattern was mainly observed in control and warming treatment, whereas in the drought treatment it was less evident. At species-specific level, a clear negative effect of drought treatment was observed for $C$. monspeliensis percentage cover. Shoot elongation was not significantly affected by the warming treatment. A significant negative effect of drought treatment was noticed in the 2001-2002 and 2002-2003 growing seasons. An increase of $\mathrm{N}$ and $\mathrm{P}$ concentrations in the drought treatment in Cistus was observed and it can be explained by the reduced shoot growth induced by the water shortage that we had observed in the same treatment. The absence of a concentration effect on the other two species could be the signal of the different behaviour with regard to a drier climate, and therefore could be a symptom of future change in species composition. We underline the need of long-term observation, because of the different responses of plants in the short and long- term conditions.

Keywords: mediterranean shrublands, plant production, night-time warming, drought period extension

\begin{abstract}
${ }^{(1)}$ Department of Forest Environment and Resources, University of Tuscia, via S. Camillo De Lellis snc - 01100 Viterbo (Italy); (2) National Research Council Institute of Biometeorology, Via Funtana di Lu Colbu, 4/A - 07100 Sassari (Italy); (3)Department of Economics and Woody Plant Ecosystems University of Sassari, via E. De Nicola, 1 07100 Sassari (Italy); ${ }^{(4)}$ National Research Council Institute of Agro-Environmental and Forest Biology, c/o Area di Ricerca, Via Salaria km. 29,3 - c.p. 10 - 00016 Monterotondo Scalo Roma (Italy)
\end{abstract}

${ }^{*}$ Corresponding Author: Paolo De Angelis (pda@unitus.it).

Citation: De Dato G, Pellizzaro G, Cesaraccio C, Sirca C, De Angelis P, Duce P, Spano D, Scarascia Mugnozza G, 2008. Effects of warmer and drier climate conditions on plant composition and biomass production in a Mediterranean shrubland community. iForest 1: 39-48 [online: Feb 28, 2008] URL: http://www.sisef.it/iforest/

\section{Introduction}

The last IPCC report predicts warmer and drier conditions for the future European climate (Kundzewicz et al. 2001). In particular, the Southern part of the continent will experience an increasing average temperature (0.1-0.4 ${ }^{\circ} \mathrm{C}$ per decade), as a consequence of increased night-time temperature (Easterling et al. 1997), and reduced precipitations, (from $-1 \%$ to $-5 \%$ per decade, Cubasch et al. 1995, Cubasch et al. 1996). Both phenomena will be mostly evident in summer, hence drier climate conditions will be likely to occur.

The Mediterranean area might be highly sensible to future climate change (Gualdi \& Navarra 2005, Peñuelas et al. 2004a, Peñuelas et al. 2004b, Ogaya et al. 2003, Carrión 2002, Peñuelas et al. 2002, Lavorel et al. 1998). In this area shrublands ecosystems represent an important vegetation component, a widespread variety resulting from degradation of Mediterranean forests caused by anthropic activities (agriculture, pasture, wood, and recently tourism, etc.) carried out for thousands of years by native populations for their purpose needs. The Italian "gariga" is a shrubland community that represents the first step of soil covering process subsequent to disturbances (fire, grazing, deforestation. An example of gariga is the formation with Cistus monspeliensis and C. creticus subsp. eriocephalus, with Dorycnium pentaphyllum (Biondi et al. 2001). The Cistus species are pyrophyte, i.e. pioneer plants spreading by seed and forming dense stands after fires (Tarrega et al. 1997). These stands represent the first step after the establishment of herbaceous plants and rustic suffrutices, such as Helichrysum italicum, that abound in poorer and more degraded edaphic conditions (Mossa et al. 1993). Climatic variation can alter the conditions that allow the evolution of this type of vegetation towards more evolved aspects, such as those represented by maquis with holm oak. The predicted lower precipitations and higher temperature may cause a general degeneration of Mediterranean forests through direct effects on plants (increased transpiration, photodamage, lower photochemical efficiency, decreased water use efficiency, decrease of productivity) and indirect effects on the abiotic component (soil erosion, nutrient leaching, more frequent wildfires - Broncano et al. 2005, Körner et al. 2005, Casermeiro et al. 2004, EEA 2004, Llorens et al. 2003, Ogaya \& Peñuelas 2003, Bakkenes et al. 2002, Honnay et al. 2002, Martinez-Mena et al. 2002, De Luis et al. 2001, Giovannini et al. 2001, Osborne et al. 2000, ScarasciaMugnozza 2000, Mossa et al. 1993). This would imply loss of habitats and species, with the migration of Southern species northwards, as reported in Skov \& Svenning (2004) and Hughes (2000).

The aim of this work was to investigate how Mediterranean shrubland ecosystems could respond to longer drought period and increased night-time temperature, which were obtained by an appropriate microclimate manipulation in an area covered by garrigue. We supposed that the increased temperature and the lower water availability would have changed the community structure, inducing a lower growth for the "more evolved" species, such as $C$. monspeliensis, in favour of the more rustic one $(H$. italic$u m)$. In a 4-year study we monitored: species cover, plant growth by measuring woody biomass, litterfall and shoot elongation, water status by leaf water potential and nutritional status by leaf chemical analysis. 


\section{Materials and Methods}

\section{Description of the area}

The experimental area (about $0.12 \mathrm{ha}$ ) is located in the peninsula of Capo Caccia (north-western Sardinia), within a Natural Reserve $\left(40^{\circ} 37^{\prime} \mathrm{N}, 8^{\circ} 10^{\prime} \mathrm{E}\right)$. Four different vegetation types can be easily identified in the area: a quite recent forested area of pine trees, the Mediterranean macchia, a Quercus ilex forest and the garrigue, located near the coast line and dominated by small bushes and tiny herbaceous plants growing between emerging rocks. The geologic substrate is Mesozoic limestone (Corrias et al. 1983). The main soil type is Terra Rossa (Lithic Xerorthent and Typic Rhodoxeralfs - USDA 1993, Valsecchi 1976, Pietracaprina 1989). The soil is rocky and shallow $(20-30 \mathrm{~cm})$; the texture is sandy loam, with an $\mathrm{ABC}$ profile, and neutral $\mathrm{pH}$.

The climate is semi-arid: the average rainfall amount is $640 \mathrm{~mm} \mathrm{yr}^{-1}$; precipitation falls in autumn and spring with a long dry period from May to August, with about 60 $\mathrm{mm}$. The mean annual temperature is 16.8 ${ }^{\circ} \mathrm{C}$. The mean of minimum temperatures in the coldest month is $7{ }^{\circ} \mathrm{C}$, the mean of the maximum temperatures in the hottest month is $28{ }^{\circ} \mathrm{C}$ (meteorological station of Fertilia Airport N 40 $38^{\prime}$ E $8^{\circ} 17^{\prime}$; altitude $40 \mathrm{~m}$ a.s.l.; sea distance $4273 \mathrm{~m}$; period of observation 1961-1990).

The experimental plots are located in a fire-break strip realized in 1973. The firebreak strip, nearly wide $125 \times 10 \mathrm{~m}$, slope $10 \%$, had been managed by controlled fire until 1990, then mechanically in 1991 and 1992. Since 1993 no other intervention has been done and vegetation started to colonize the soil. The plots are covered by vegetation with a maximum height of $1.0 \mathrm{~m}$ mainly represented by Cistus monspeliensis, Helichrysum italicum and Dorycnium pentaphyllum. The presence of other shrubs (Pistacia lentiscus, C. creticus, Daphne gnidium, etc.) is more sporadic. Bare soil is about $20 \%$ of soil cover.

\section{Microclimate manipulation and climate monitoring}

The experimental manipulation of climate conditions at field scale was carried out employing a newly developed night-time warming technique and an automated covering system to extend summer drought (Beier et al. 2004; Fig. 1). Extended summer drought was induced by covering the plots with waterproof plastic curtains, transparent to infrared radiation, during rain events that occurred during two periods per year, in spring and in autumn (May $1^{\text {st }}$ - June $13^{\text {th }} 2002 ; \mathrm{Au}-$ gust $27^{\text {th }}-$ November $15^{\text {th }} 2002$; April $1^{\text {st }}$. May $31^{\text {st }} 2003$; October $1^{\text {st }}-$ November $30^{\text {th }}$ 2003; April $1^{\text {st }}$ - May $31^{\text {st }} 2004$; October $1^{\text {st }}$. November $30^{\text {th }}$ 2004). Passive night-time warming was induced throughout the year by covering vegetation and soil with aluminium curtains at night. This method enables the ecosystem to retain a portion of energy accumulated during the light period, simulating the mechanism of global warming. The curtains run along two rails placed on a light scaffolding $1.5 \mathrm{~m}$ tall. The curtains were coiled on a beam and connected to a motor. The movement of the curtains was controlled automatically by an electronic devise set to the following conditions:

- the warmed plots were automatically covered when light intensity at sunset was lower than $0.4 \mathrm{~W} \mathrm{~m}^{2}$. At sunrise the curtains were retracted to leave the plots open during the day;

- a rain sensor activated the curtains to cover the drought plots whenever it rained and to remove them when it stopped. The water collected by the curtains was removed from the area by gutters;

- to keep the hydrological conditions in the warmed plots unaffected, rain sensor activated the removal of the curtains in case of rain during the night (sensitivity $<0.3$ $\mathrm{mm}$ ). When the rain stopped, the curtains were automatically drawn over the vegetation again.

Twenty $\mathrm{m}^{2}$ plots $(5 \times 4 \mathrm{~m})$ were manipulated by night-time warming and extending drought, and the responses to the treatments were compared to the control plots. Each type of manipulation was replicated 3 times. Pre-treatment measures were conducted to identify variability between sites or plots.

In each plot, air temperature and relative humidity at $20 \mathrm{~cm}$ height from soil (Igromer HP100A, Rotronic, CH), soil temperature at $10 \mathrm{~cm}$ depth and at $20 \mathrm{~cm}$ depth (LTN NR3, Tecno.El, IT) and soil water content (ECH2O probe model EC-20, Decagon Devices, Inc.) at $10 \mathrm{~cm}$ depth were continuously monitored. Moreover, a weather station measured air temperature and relative humidity (Igromer HP100A, Rotronic, CH), wind direction and speed (03002 Young, USA), global solar radiation (PYR SKS1110, Skye Instruments, UK) and precipitation (ARG199, Environmental Measurements, UK) at $2 \mathrm{~m}$ height. The opening and closing time of the curtains were recorded for each plot by sensors (Mac-I) installed along the rails. These sensors allow to check the good working of the curtains and, when compared to the time of raining, to calculate the amount of precipitation removed. All the sensors were acquired and stored in a data logger (CR10X Campbell Scientific, Inc., USA) and downloaded on a laptop every week nearly.

The average temperatures were calculated for the growing season, covering the months from September, when the autumn precipitations occur, till May, before the beginning of the summer dry period.

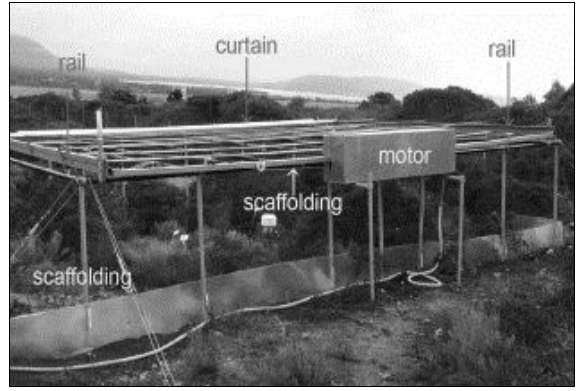

Fig. 1 - The plot is delimited by light scaffolding, upon which two rails allow the curtains to run and mimic the climate change. For more details see the text.

\section{Plant cover}

The pinpoint method (Troumbis \& Memtsas 2000, Merino et al. 1990) was used in order to measure plant frequency, and to indirectly estimate plant cover. A sharpened pin was lowered through the vegetation along different transects. Each plant hit with the pin was counted and the plant species and type of contact recorded. 300 measurements for each plot were collected. Two different contact types were identified: vegetative parts (green and dead) and reproductive structures (flowers, inflorescences, and fruits). The total number of hits for each species (and for each part of plant) per transect was expressed as portion of all the pin per transect. Pre-treatment measurements were done in summer 2001 to identify variability between plots. The measurement frequency was yearly, during the first two weeks of May, at the peak of the growing season, except in 2001 when the campaign was done in June.

\section{Plant biomass}

Plant dimensions were calibrated against woody biomass using destructive sampling outside the plots. In winter 2001 inside an external plot $(5 \times 5 \mathrm{~m})$ the maximum height $(\mathrm{H})$ and the two orthogonal maximum crown diameters $\left(D_{\mathrm{cl}}\right.$ and $\left.\mathrm{D}_{\mathrm{c} 2}\right)$ were taken for the following perennial plants (C. monspeliensis, $H$. italicum, D. pentaphyllum, $P$. lentiscus and $C$. creticus). The plants were then harvested. The collected material was dried at $70{ }^{\circ} \mathrm{C}$ up to constant weight and then weighed to measure the dry woody biomass (DWB). Given the projected crown area $\left(\mathrm{A}_{\mathrm{c}}\right)$ equal to (eqn. 1):

$$
A_{c}=\pi\left(D_{c 1} / 2\right) *\left(D_{c 2} / 2\right)
$$

The apparent volume $\left(V_{\mathrm{a}}\right)$ of each plant was calculated as (eqn. 2 ):

$$
V_{a}=A_{c} \cdot H
$$

Five different relationships for the $i$ species $(i=5)$ between the $\mathrm{V}_{\mathrm{a}}$ and DWB were found (eqn. 3):

$$
D W B_{i}=a_{i} \cdot V_{a i}
$$


Tab. 1 - (a) Growing season (September-May) daily mean temperatures of air (Ta), soil at $10 \mathrm{~cm}$ depth (Ts10) and soil at $20 \mathrm{~cm}$ depth (Ts20); (b) Growing season (September-May) daily mean minimum temperatures of air (Ta), soil at $10 \mathrm{~cm}$ depth (Ts10) and soil at $20 \mathrm{~cm}$ depth (Ts20). The following symbols indicate significant differences between the warming treatment and the control: ${ }^{* * *} \mathrm{p}<0.001 ;{ }^{\text {[a] }} \mathrm{p}<$ 0.06 .

\begin{tabular}{|c|c|c|c|c|c|c|c|c|c|}
\hline \multirow{2}{*}{$\begin{array}{l}\text { (a) } \\
\text { Year }\end{array}$} & \multicolumn{3}{|c|}{ Ta } & \multicolumn{3}{|c|}{ Ts10 } & \multicolumn{3}{|c|}{ Ts20 } \\
\hline & $\begin{array}{c}\text { Control } \\
\left({ }^{\circ} \mathrm{C}\right)\end{array}$ & $\begin{array}{c}\text { Warming } \\
\left({ }^{\circ} \mathrm{C}\right)\end{array}$ & $\begin{array}{c}\text { Effect } \\
(\%)\end{array}$ & $\begin{array}{c}\text { Control } \\
\left({ }^{\circ} \mathrm{C}\right)\end{array}$ & $\begin{array}{c}\text { Warming } \\
\left({ }^{\circ} \mathrm{C}\right)\end{array}$ & $\begin{array}{c}\text { Effect } \\
(\%)\end{array}$ & $\begin{array}{c}\text { Control } \\
\left({ }^{\circ} \mathrm{C}\right)\end{array}$ & $\begin{array}{c}\text { Warming } \\
\left({ }^{\circ} \mathrm{C}\right)\end{array}$ & $\begin{array}{c}\text { Effect } \\
(\%)\end{array}$ \\
\hline $2001-2002$ & 14 & 14 & $+2.2 * * *$ & 14 & 15 & $+3.9 * * *$ & 15 & 16 & $+2.7 * * *$ \\
\hline $2002-2003$ & 13 & 14 & $+1.9 * * *$ & 14 & 14 & $-0.2^{[\mathrm{a}]}$ & 15 & 15 & $-2.2 * * *$ \\
\hline 2003-2004 & 13 & 13 & $+3.6^{* * *}$ & 14 & 14 & $+0.8 * * *$ & 14 & 15 & $+1.4 * * *$ \\
\hline \multirow{2}{*}{$\begin{array}{l}\text { (b) } \\
\text { Year }\end{array}$} & \multicolumn{3}{|c|}{$\begin{array}{c}\text { Ta } \\
\text { (min) }\end{array}$} & \multicolumn{3}{|c|}{$\begin{array}{l}\text { Ts10 } \\
\text { (min) }\end{array}$} & \multicolumn{3}{|c|}{$\begin{array}{l}\text { Ts20 } \\
(\min )\end{array}$} \\
\hline & $\begin{array}{c}\text { Control } \\
\left({ }^{\circ} \mathrm{C}\right)\end{array}$ & $\begin{array}{c}\text { Warming } \\
\left({ }^{\circ} \mathrm{C}\right)\end{array}$ & $\begin{array}{c}\text { Effect } \\
(\%)\end{array}$ & $\begin{array}{c}\text { Control } \\
\left({ }^{\circ} \mathrm{C}\right)\end{array}$ & $\begin{array}{c}\text { Warming } \\
\left({ }^{\circ} \mathrm{C}\right)\end{array}$ & $\begin{array}{c}\text { Effect } \\
(\%)\end{array}$ & $\begin{array}{c}\text { Control } \\
\left({ }^{\circ} \mathrm{C}\right)\end{array}$ & $\begin{array}{c}\text { Warming } \\
\left({ }^{\circ} \mathrm{C}\right)\end{array}$ & $\begin{array}{c}\text { Effect } \\
(\%)\end{array}$ \\
\hline $2001-2002$ & 8 & 9 & $+9.8 * * *$ & 13 & 14 & $+6.7 * * *$ & 14 & 15 & $+5.0 * * *$ \\
\hline $2002-2003$ & 6 & 7 & $+14.7 * * *$ & 12 & 12 & $+3.7 * * *$ & 13 & 13 & $+1.5^{* * *}$ \\
\hline 2003-2004 & 7 & 8 & $+12.4 * * *$ & 12 & 13 & $+4.1 * * *$ & 13 & 14 & $+2.1 * * *$ \\
\hline
\end{tabular}

where a is the estimated coefficient. The apparent volume has been widely used to determine the aerial biomass in polycormic plants of the Mediterranean region (Sternberg \& Shoshany 2001, Usó et al. 1997).

In early spring 2002 and 2004, $H$ and $\mathrm{D}_{\mathrm{c}}$ of the perennial species were measured inside the nine experimental plots, and the standing plant woody biomass was estimated by the equation 3 .

The annual growth rate $(A G R)$ was calcu-

$$
A G R=\frac{\left(D W B_{2004}-D W B_{2002}\right) / D W B_{2002}}{2} \cdot 100
$$

where 2004 and 2002 represent the sampling years.

\section{Litterfall}

In each plot, 10 litterfall collectors were located under the canopy of plants according to their cover. Each collector was made of PVC tubes with a circular area of $385 \mathrm{~cm}^{2}$ lated as (eqn. 4):

and $20 \mathrm{~cm}$ high. The bottom of the collector was closed with a net $\left(0.25 \mathrm{~mm}^{2}\right)$ to prevent material loss. The material was collected, dried in oven and weighed up to constant weight almost monthly.

\section{Plant shoots growth}

Direct measurements of plant growth were carried out for the most dominant species (C. monspeliensis). At the beginning of the vegetative cycle (September), every year a sample of 10 shoots was labelled in each plot. The shoots were harvested in March when maximum elongation of terminal main shoots was reached and flower buds appeared at the apex of shoots. For each shoot the following parameters were measured: length of the main shoot, orthogonal basal diameters, number of leaves, and leaf area.

\section{Leaf chemical composition}

Leaves of upper-canopy were sampled every year to determine leaf chemical com-

Tab. 2 - Mean annual biomass accumulation $\left(\mathrm{g} \mathrm{m}^{-2} \mathrm{yr}^{-1}\right)$ calculated during the period 20022004. $\mathrm{CM}=$ Cistus monspeliensis $; \mathrm{CC}=C$. creticus $; \mathrm{PL}=$ Pistacia lentiscus $; \mathrm{HM}=$ Helichrysum italicum $; \mathrm{DP}=$ Dorycnium pentaphyllum; TOT $=$ above ground biomass growth of the total biomass. D.OFF = period with the Drought treatment turned off.

\begin{tabular}{clcc}
\hline \multirow{2}{*}{ Growing season } & \multicolumn{1}{c}{ Period } & $\begin{array}{c}\text { Day of } \\
\text { Drought treatment }\end{array}$ & Precipitation (mm) \\
\cline { 4 - 4 } $2001-2002$ & $1^{\text {st }}$ period & 61 & Control \\
\hline & $2^{\text {nd }}$ period & 30 & 1 \\
& D.OFF & - & 38 \\
& annual & 91 & 199 \\
\hline $2002-2003$ & $1^{\text {st }}$ period & 76 & 238 \\
& $2^{\text {nd }}$ period & 54 & 152 \\
& D.OFF & - & 9 \\
& annual & 130 & 252 \\
\hline $2003-2004$ & $1^{\text {st }}$ period & 60 & 412 \\
& $2^{\text {nd }}$ period & 61 & 178 \\
& D.OFF & - & 146 \\
& annual & 121 & 188 \\
\hline
\end{tabular}

position. $\mathrm{C}$ and $\mathrm{N}$ concentrations were determined by elemental analyzer (Carlo Erba model 1108EA, Milan, IT). P concentration was determined by colorimetry using the blu-molibdathe method described in Allen (1974).

\section{Predawn water potential}

Xilematic pre-dawn water potential was measured from April 2002 to August 2004 every two months on $C$. monspeliensis by pressure chamber (model SKPM 1400, Skye Instruments LTD, UK). Before dawn, one shoot per plant was cut after enclosure in a plastic bag and measured in one minute. Three plants of for each plot were measured in each sampling date, for a total of 27 measurements.

\section{Statistical analysis}

The effect of warming and drought treatments on the air and soil temperatures was tested by a Wilcoxon signed rank test. We tested if the daily temperature differences (warming minus control and drought minus control, respectively) could be assumed to be higher than zero.

One-way ANOVAs with plant variables as dependent variable and treatment as independent factor was performed for each year (or date) to compare warming and drought treatments separately with control treatment. We considered the plot as the smallest independent unit; therefore we used the average value of each variable per plot $(n=3$ per treatment), except for shoots. Significant differences between means were identified by Duncan's multiple range test.

The plant cover results relative to the whole community and to the three dominant species (C. monspeliensis, H. italicum and $D$. pentaphyllum) were subjected to regression analysis in order to describe, for each treatment, the trend of this variable during 
Fig. 2 - Soil cover percentage by the different species at the pre-treatment (2001). The values are the average of the nine plots.

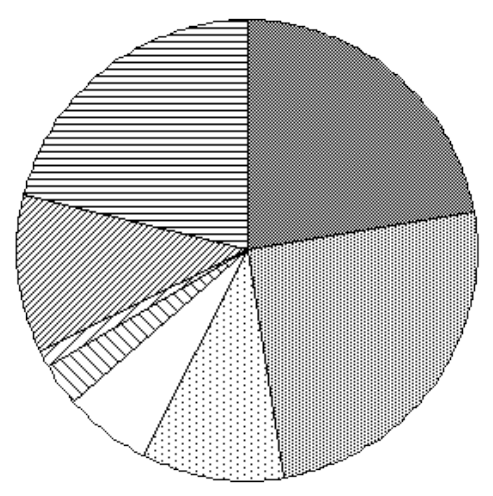

H. italicum

C. monspeliensis

D. pentaphyllum

$P$. lentiscus

C. creticus

R. officinalis

other species

bare soil the experiment. Significant differences between coefficient slope relative to control and each treatment were identified by Student's test.

Leaf chemical composition differences were tested by a two-way ANOVA. The mean value per plot for each nutrient $(n=3$ per treatment) was used as dependent variable. Nutrients and species were analyzed separately. Year $(n=4)$ and treatment $(n=$ 3 ) were the independent variables.

\section{Results and discussion}

Effect of the treatments on microclimate

The warming treatment increased significantly soil and air temperature during the three growing seasons (Tab. 1). The effects on the minimum air temperatures were on average $+0.9^{\circ} \mathrm{C},+0.6{ }^{\circ} \mathrm{C}$ and $+0.4{ }^{\circ} \mathrm{C}$, measured respectively at $+20 \mathrm{~cm}(\mathrm{Ta}),-10 \mathrm{~cm}$ (Ts10) and $-20 \mathrm{~cm}$ (Ts20). As a consequence of the higher minimum temperatures, the daily mean temperatures were significantly affected as well: the strongest effect was on $\mathrm{Ta}\left(+0.3{ }^{\circ} \mathrm{C}\right)$; the effect on Ts 10 was positive in 2001-2002, but in 2002-2003 and 20032004 it was almost null; Ts20 was warmer in 2001-2002 and 2003-2004, and it was colder in 2002-2003.

The removed precipitation amounts (sum of the two periods - Tab. 2), expressed as percentage of the total precipitation fallen during the growing season, were $6 \%, 18 \%$ and $46 \%$ respectively in $2001-2002,2002$ 2003 and 2003-2004. The system was not always effective in cutting rain, as occurred during the autumn of the first growing season and during the spring of the second growing season.

The effect of reduced precipitations on soil water content was not always evident, because of the high heterogeneity of soil, and because of the low number of sampling points per plot (Netto et al. 1999). Mean soil relative water contents (normalized to the annual maximum soil water content) during the drought were decreased by $2 \%(\mathrm{t}$ value $=$ $-1.5, \mathrm{p}=0.13), 8 \%(\mathrm{t}$ value $=-7.2, \mathrm{p}<0.001)$ and $3 \%(\mathrm{t}$ value $=-2.7, \mathrm{p}<0.01)$, respectively in 2001-2002, 2002-2003 and 20032004.

As previously reported in De Angelis et al. (2005), the obtained change in microclimate other climate manipulative experiments (Hollister et al. 2005, Sardans \& Peñuelas 2004, Sardans \& Peñuelas 2005, Nijs et al. 1996). Nevertheless, this was the tribute to pay to obtain one of the main objective of the used device, i.e. avoiding the secondary effects of devices as OTCs, electrical wires and infrared lamps (Saavedra et al. 2003, Wan et al. 2002, Turnbull et al. 2002, Strömgren \& Linder 2002, Shaver et al. 2000, Norby et al. 1997, Harte \& Shaw 1995), which included interaction with water cycle and undifferentiated increase in day- and night-time temperatures. On the other hand, our microclimate manipulation was realistic because it altered meanly night-time temperature and prolonged the summer dry period,

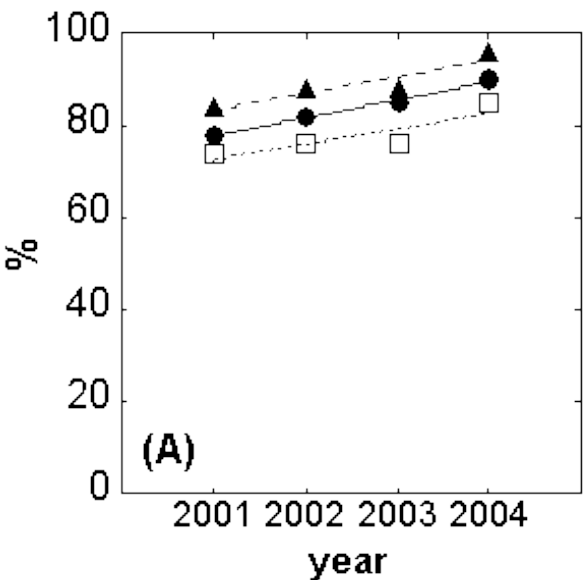
was not of the same magnitude compared to that is what the instrumental records had revealed for the last decades (Folland et al. 2001, Easterling et al. 1997). Additionally, Kundzewicz et al. (2001) report for the future an increase in air temperature by 0.1-0.4 ${ }^{\circ} \mathrm{C}$ per decade and a change in summer precipitations by $-5 \%$ per decade, so that the simulated climate, obtained by the described devices, and the below reported plant responses, seem to mirror in a realistic way the situation in the short or medium-term of 10 50 years.

\section{Change in plant cover}

Pre-treatment measurements (late spring 2001) did not show significant differences between treatments in term of percentage of cover and reproductive effort. C. monspeliensis, $H$. italicum and $D$. pentaphyllum provided almost $60 \%$ of soil cover; about $21 \%$ of soil was covered by other species, the main of which was $P$. lentiscus and $C$. creticus; about one fifth of soil was classified as bare soil (Fig. 2).

A general increase of vegetation cover was observed in the whole community during the three years of experimentation, even if the increase of this parameter in warming and drought treatment was almost null in 2003. This positive temporal pattern was mainly observed in control and warming treatment $(\mathrm{p}=0.01$ and 0.07 in control and warming respectively) whereas in the drought treatment it was less evident ( $p=0.14$ - Fig. 3A). No significant differences between regression slopes were observed.

At species-specific level, a clear negative effect of drought treatment was observed for C. monspeliensis percentage cover. The trend line, in fact, showed a negative slope significantly different from the one of control, ( $p<0.05$ - Fig. 3B). No particular effect of warming was observed on this species. On the contrary, $H$. italicum and $D$. pentaphyl-

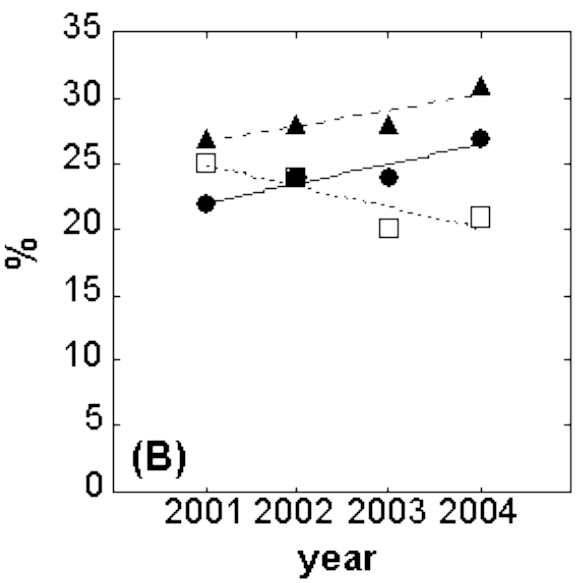

Fig. 3 - Trend line of cover percentage observed: (a) for the whole community, and (b) for Cistus monspeliensis in treated and non-treated plots during the years of experimentation. Full circles with continuous line $=$ Control; full triangles with dash line $=$ Warming; open squares with dot line $=$ Drought. 
lum did not show any identifiable temporal trend either in treated or in non-treated plots (data not shown).

The positive temporal trend of the total cover observed in the control and warming treatment, except that in the drought ones (Fig. 3A) seems to indicate that the evolutionary process of plant community has not stopped after 12 years (after the last disturbance in 1993) since the fire-break strip has no longer been managed. This behaviour is similar to those reported by other studies (Calvo et al. 2002), where plant cover had been recovered in 12-15 years after the disturbances. However, our climate and edaphic conditions could explain the quite slow evolution of the vegetation community.

The negative trend observed for the Cistus cover in the drought treatment (Fig. 3B) gives evidence to the negative effect of water shortage on the evolution of this community. This idea is corroborated by the fact that in 2001 (pre-treatment) we had observed an inverse relationship between plant cover of

Tab. 3 - Parameters of the allometric regression $\mathrm{DWB}_{\mathrm{i}}=\mathrm{a} \mathrm{i} * \mathrm{~V}_{\mathrm{ai}}$ used to estimate the aerial biomass of the five mentioned species.

\begin{tabular}{lcccc}
\hline \multicolumn{1}{c}{ Species } & $\mathbf{a}$ & $\mathbf{n}$ & $\mathbf{r}^{2}$ & $\mathbf{p}$ \\
\hline C. monspeli- & $1311.8 \pm$ & 12 & 0 & $\mathrm{p}<0.001$ \\
ensis & 76.2 & & & \\
H. italicum & $2364.4 \pm$ & 24 & 0 & $\mathrm{p}<0.001$ \\
& 243.7 & & & \\
P. lentiscus & $2364.4 \pm$ & 4 & 0 & $\mathrm{p}<0.01$ \\
& 243.7 & & & \\
D. pentaphyl- & $577.6 \pm$ & 11 & 0 & $\mathrm{p}<0.01$ \\
lum & 17.4 & & & \\
C. incanus & $2969.1 \pm$ & 13 & 0 & $\mathrm{p}<0.01$ \\
& 437.4 & & & \\
\hline
\end{tabular}

Cistus and Helichrysum in the nine plots; therefore it could be plausible to think of an exclusive use of space. Moreover, the carbon isotopic composition of leaves (as reported in De Dato 2004) had demonstrated that Cistus plants were negatively influenced in their stomatal response by the drought treatment, effect not observed in Helichrysum. If the negative trend in Cistus cover is confirmed in the future, we could assert that the evolutionary phases of this ecosystem will be blocked and, on the contrary, the less evolved steps will find enough space and resources to expand. Considering that the cycles of plant adaptation and recovery after disturbances are longer than the 4 years of the present study (Hollister et al. 2005, Epstein et al. 2004, Calvo et al. 2002, Tarrega et al. 2001), a longer-term experiment could give more clear responses about the behaviour of plants at specific and functional group level.

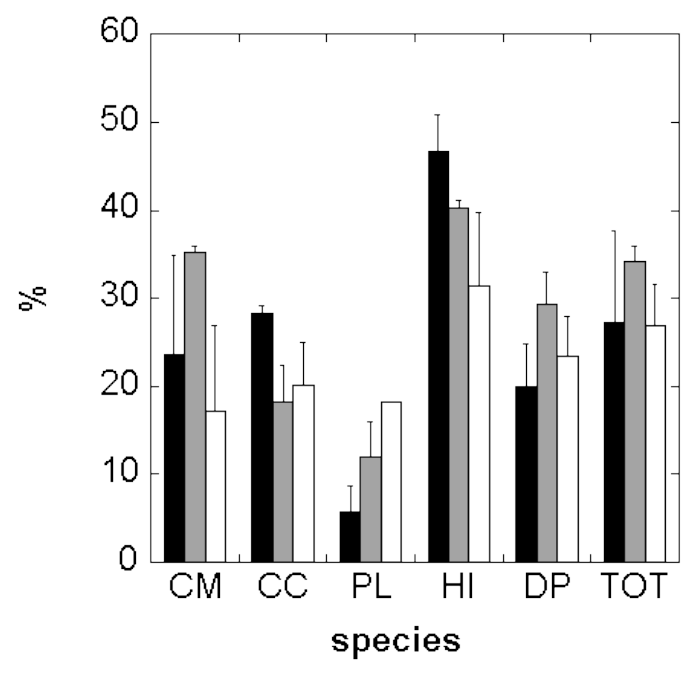

Fig. 4 - Annual growth rate calculated in the period 2002-2004. Control $=$ Black bars; Warming = Grey bars; Drought $=$ White bars. $\mathrm{CM}=$ Cistus monspeliensis $; \mathrm{CC}=$ C. creticus; $\mathrm{PL}=$ Pistacia lentiscus; $\mathrm{HM}=$ Helichrysum italicum; $\mathrm{DP}=$ Dorycnium pentaphyllum; $\mathrm{TOT}=$ above ground biomass growth rate of the total biomass.

\section{Effects on plant growth and litterfall}

In 2002 the estimated above ground standing woody biomass inside the experimental plots varied between 328 and $545 \mathrm{~g} \mathrm{~m}^{-2}$. On average $72 \%$ of this amount was due to the sum of C. monspeliensis and H. italicum biomasses. D. pentaphyllum, $C$. creticus and $P$. lentiscus contributed on average with $19 \%$, $6 \%$ and $4 \%$ respectively.

In the control treatment the annual growth rate (AGR - Fig. 4) for the period 2002-2004 was $27 \%$; in the warming treatment it was $34 \%$ and in the drought treatment it was $27 \%$, not significantly different between the treated and non-treated plots. In terms of biomass, this is equivalent to an increase of only about $60 \mathrm{~g} \mathrm{~m}^{-2} \mathrm{yr}^{-1}$ of woody dry weight, averaged between the two years (Tab. 3).

Shoots basal diameter of $C$. monspeliensis was not significantly affected by the warming treatment, whereas the drought treatment inhibited significantly this parameter during the growing seasons 2001-2002 and 20032004 ( $-15 \%$ and $-10 \%$ respectively, $\mathrm{p}<0.05)$, but not in the 2002-2003 growing season $(-6 \%, p=0.4-$ Tab. 4$)$.

Shoot elongation was not significantly affected by the warming treatment. A significant negative effect of drought treatment was noticed in the 2001-2002 and 2002-2003 growing seasons $(-21 \%$ in both the year; $\mathrm{p}<$ 0.05 ) but not in 2003-2004 ( $p=0.7$ - Tab. 4).

The warming treatment did not have effect on the other parameters in the 2002-2003 and 2003-2004 growing seasons. The drought treatment had a negative effect on the mean leaf area in the 2003-2004 growing season $(\mathrm{p}<0.05-\mathrm{Tab} .4)$.

The observed changes in the shoot growth were caused by a rainfall decrease and by the consequent change in soil water content. These results match with the experimental findings, that derive from studies carried on both in shrublands and maquis species and in conifer forests (Körner et al. 2005, Peñuelas et al. 2004a, Llorens et al. 2003, Ogaya et al. 2003, Cinnirella et al. 2002, Rovira et al. 2002) of the Mediterranean basin, which all claimed water availability as the limiting factor for plants of this area and showed that decreased precipitations could have a central role for plant productivity. This experiment, in addition, stress this characteristic, given that the experimentally drought was not a permanent stress, but it was carried out on only during the growing seasons. Moreover, different periods of the drought treatment brought different results on shoot elongation. In fact, the drought treatment in the autumn 2001 and 2002 (growing seasons 2001-2002 and 2003-2004 respectively) removed summer precipitations, because it run from September to October, causing a slightly recover of the soil water content and therefore a stronger effect on shoot elongation, that starts after the dry summer whenever the first rains fall; on the contrary, in the autumn

Tab. 4 - Annual biomass accumulation $\left(\mathrm{g} \mathrm{m}^{-2} \mathrm{yr}^{-1}\right)$ calculated during the period 2002-2004. [a] = above ground biomass growth of the total biomass.

\begin{tabular}{lccc}
\hline \multicolumn{1}{c}{$\mathbf{g ~ m ~}^{-2} \mathbf{y r}^{-1}$} & Control & Warming & Drought \\
\hline Cistus monspeliensis & $13.7( \pm 5.3)$ & $21.5( \pm 5.2)$ & $22.7( \pm 16.5)$ \\
C. creticus & $4.7( \pm 3.1)$ & $0.7( \pm 0.3)$ & $2.9( \pm 1.1)$ \\
Pistacia lentiscus & $0.6( \pm 0.5)$ & $0.9( \pm 0.4)$ & $5.0(--)$ \\
Helichrysum italicum & $36.3( \pm 18.1)$ & $28.8( \pm 17.1)$ & $21.3( \pm 13.0)$ \\
Dorycnium pentaphyllum & $6.0( \pm 3.2)$ & $11.6( \pm 6.1)$ & $8.0( \pm 2.0)$ \\
Total $^{\text {[a] }}$ & $61.2( \pm 23.2)$ & $63.5( \pm 7.4)$ & $56.6( \pm 17.3)$ \\
\hline
\end{tabular}


Fig. 5 - Monthly leaf litterfall of the entire community. In order to simplify, standard errors are not drawn. Control $=$ full circles with continuous line; Warming = full triangles with long dash line; Drought $=$ open squares with short dash.

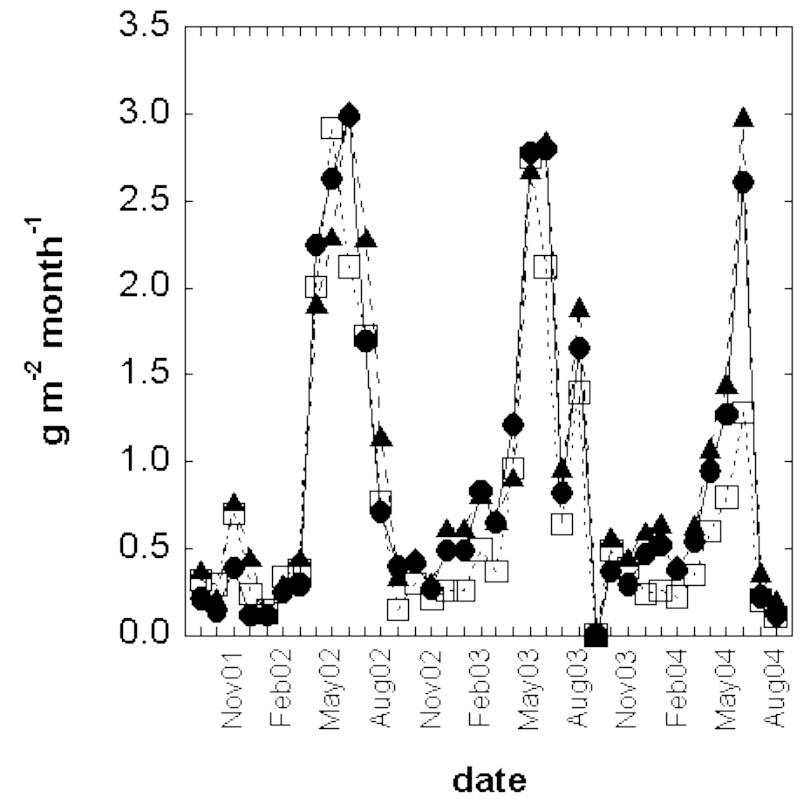

Tab. 5 - Shoot length ( \pm s.e.) and diameter ( \pm s.e.) of $C$. monspeliensis per year and treatment. Different letters mean significant differences among the treatments $(p<0.05) ;$ n.a. $=$ not available.

\begin{tabular}{|c|c|c|c|c|c|c|}
\hline $\begin{array}{c}\text { Growing } \\
\text { season }\end{array}$ & Treatment & $\begin{array}{l}\text { Shoot dia- } \\
\text { meter } \\
(\mathrm{mm})\end{array}$ & $\begin{array}{l}\text { Shoot } \\
\text { length } \\
\text { (cm) }\end{array}$ & $\begin{array}{l}\text { Total leaf } \\
\text { area }\left(\mathrm{cm}^{2}\right)\end{array}$ & $\begin{array}{c}\text { \# leaves } \\
\text { shoot }^{-1}\end{array}$ & $\begin{array}{l}\text { Mean leaf } \\
\text { area }\left(\mathrm{cm}^{2}\right)\end{array}$ \\
\hline \multirow[t]{3}{*}{ 2001-2002 } & Control & $2.0 \pm 0.11 \mathrm{a}$ & $6.9 \pm 0.5 \mathrm{a}$ & n.a. & n.a. & n.a. \\
\hline & Warming & $1.8 \pm 0.07 \mathrm{ab}$ & $6.0 \pm 0.3 \mathrm{ab}$ & & n.a. & n.a. \\
\hline & Drought & $1.7 \pm 0.05 \mathrm{~b}$ & $5.3 \pm 0.3 \mathrm{~b}$ & n.a. & n.a. & n.a. \\
\hline \multirow[t]{3}{*}{$2002-2003$} & Control & $1.8 \pm 0.08 \mathrm{a}$ & $7.8 \pm 0.5 \mathrm{a}$ & $32.8 \pm 3.4 \mathrm{a}$ & $42.6 \pm 3.9 \mathrm{a}$ & $0.77 \pm 0.04 \mathrm{a}$ \\
\hline & Warming & $1.9 \pm 0.04 \mathrm{a}$ & $7.8 \pm 0.3 \mathrm{a}$ & $33.2 \pm 3.0 \mathrm{a}$ & $44.0 \pm 4.0 \mathrm{a}$ & $0.81 \pm 0.07 \mathrm{a}$ \\
\hline & Drought & $1.7 \pm 0.07 \mathrm{a}$ & $6.2 \pm 0.5 \mathrm{~b}$ & $28.6 \pm 3.3 \mathrm{a}$ & $33.3 \pm 2.9 \mathrm{a}$ & $0.85 \pm 0.05 \mathrm{a}$ \\
\hline \multirow[t]{3}{*}{ 2003-2004 } & Control & $2.0 \pm 0.06 \mathrm{a}$ & $6.2 \pm 0.4 \mathrm{a}$ & $29.1 \pm 3.3 \mathrm{ab}$ & $54.7 \pm 4.9 a$ & $0.54 \pm 0.04 \mathrm{a}$ \\
\hline & Warming & $2.0 \pm 0.07 \mathrm{a}$ & $7.2 \pm 0.5 \mathrm{a}$ & $33.9 \pm 2.9 \mathrm{a}$ & $59.1 \pm 4.3 \mathrm{a}$ & $0.57 \pm 0.02 \mathrm{a}$ \\
\hline & Drought & $1.7 \pm 0.05 \mathrm{~b}$ & $5.7 \pm 0.5 \mathrm{a}$ & $20.6 \pm 2.1 \mathrm{~b}$ & $45.8 \pm 4.4 \mathrm{a}$ & $0.41 \pm 0.02 \mathrm{a}$ \\
\hline
\end{tabular}

2003 (growing season 2003-2004) the drought treatment run later (OctoberNovember), when soil water recharge had already occurred and the shoot growth had already started. Considering the biomass growth at the community level, no significant effect was found. This is not in contrast with the change in shoot elongation, because shoot elongation is a more precise measure and moreover it is a more sensible parameter than biomass accumulation especially in the short period (in this study we are testing only three growing seasons).

Differently from the drought treatment, warmer temperatures did not bring any positive or negative effect on plant and shoot growth (Tab. 4). In temperate and boreal regions, warming experiments had induced higher plant growth (Rustad et al. 2001). In the Mediterranean area, where temperature is already optimal, neither stimulation effect on photosynthesis or on vegetative period lengthening can be plausible (Peñuelas et al. 2004a). In this site, in fact, Cesaraccio et al. (2004) did not find any significant elongation of the vegetative period. De Dato 2004) did not report, for the same site, positive effect of the warming treatment on litter decomposition process and on the soil $\mathrm{CO}_{2}$ efflux. In a parallel experiment on a shrubland community in Spain, Llorens et al. (2003) did not report a significant change of net photosynthesis at higher temperatures.

The leaf litterfall amount calculation was per each growing season. based, as for the biomass, on the growing season, that is to say considering the litter fallen during the period from September of the year $n$ until August of the year $n+1$. In the control treatment (Tab. 5), leaf litterfall was $51.1,52.0$ and $34.2 \mathrm{~g} \mathrm{~m}^{-2}$ period ${ }^{-1}$ respectively during the growing seasons 2001 2002, 2002-2003 and 2003-2004. C. monspeliensis produced most of the litter (70$80 \%$ of all the collected material). The warming treatment increased the litterfall production by $+13 \%,+2 \%$ and $+20 \%$ respectively in the 2001-2002, 2002-2003 and 2003-2004 growing seasons compared to the control. In the drought plots litterfall production was between 51.6 and $21.6 \mathrm{~g} \mathrm{~m}^{-2}$ period ${ }^{1}$, lower than the control values by $23 \% 37 \%$ in the 2002-2003 and 2003-2004, but the difference was $+1 \%$ in the 2001-2002. All these effects were never statistically significant. The maximum in the litterfall occurred in summer (June-July), as typical of the drought-avoiding plants with summer-deciduousness habit (Fig. 5), with no differences between the control and the warming and drought treatments. According to several authors (Pavón et al. 2005, Alegre et al. 2004, Simmons et al. 1996), litter production is strongly controlled by precipitation, following a direct relationship (lower the precipitation, lower the litter production). Moreover, Pavón et al. (2005) showed that temperature was negatively related to litterfall amount. The lack of treatment effect in the present study was unexpected, the high standard errors of the data are the results of the different percentage distributions of the species inside the plots. However, it is in accordance with the lack of treatments response in the biomass growth and in the number of leaves per shoot (Fig. 4, Tab. 4).

\section{Leaf chemical composition}

Leaf $\mathrm{C}$ concentration was approximately $50 \%$ in the analyzed species (Fig. 6 a-b-c, Tab. 7). This value followed a slightly significant decreasing trend in the three species, but no effect due to the treatments was ever noticed.

Leaf $\mathrm{N}$ concentration at the pre-treatment was between $1.2-2.2 \%$, with $D$. pentahyllum the richest species (Fig. 6 d-e-f, Tab. 7). In Cistus leaves a significant higher value of the mean $\mathrm{N}$ concentration in the drought than in the control treatment (about $+10 \%$ ) was found. The warming treatment did not alter

Tab. 6 - Leaf litterfall production ( \pm s.e.) during the three growing seasons, expressed as $g$ $\mathrm{m}^{-2}$ period ${ }^{-1}$. Different letters indicate significant differences $(\mathrm{p}<0.05)$ among the treatments

\begin{tabular}{clll}
\hline $\begin{array}{c}\mathbf{g ~ m}^{-2} \\
\text { period }^{-\mathbf{1}}\end{array}$ & Control & Warming & Drought \\
\hline $2001-2002$ & $51.1( \pm 12.3) \mathrm{a}$ & $57.7( \pm 6.6) \mathrm{a}$ & $51.6( \pm 22.1) \mathrm{a}$ \\
$2002-2003$ & $52.0( \pm 12.3) \mathrm{a}$ & $52.8( \pm 7.5) \mathrm{a}$ & $40.0( \pm 9.9) \mathrm{a}$ \\
$2003-2004$ & $34.2( \pm 7.0) \mathrm{a}$ & $41.0( \pm 2.6) \mathrm{a}$ & $21.6( \pm 5.2) \mathrm{a}$ \\
\hline
\end{tabular}



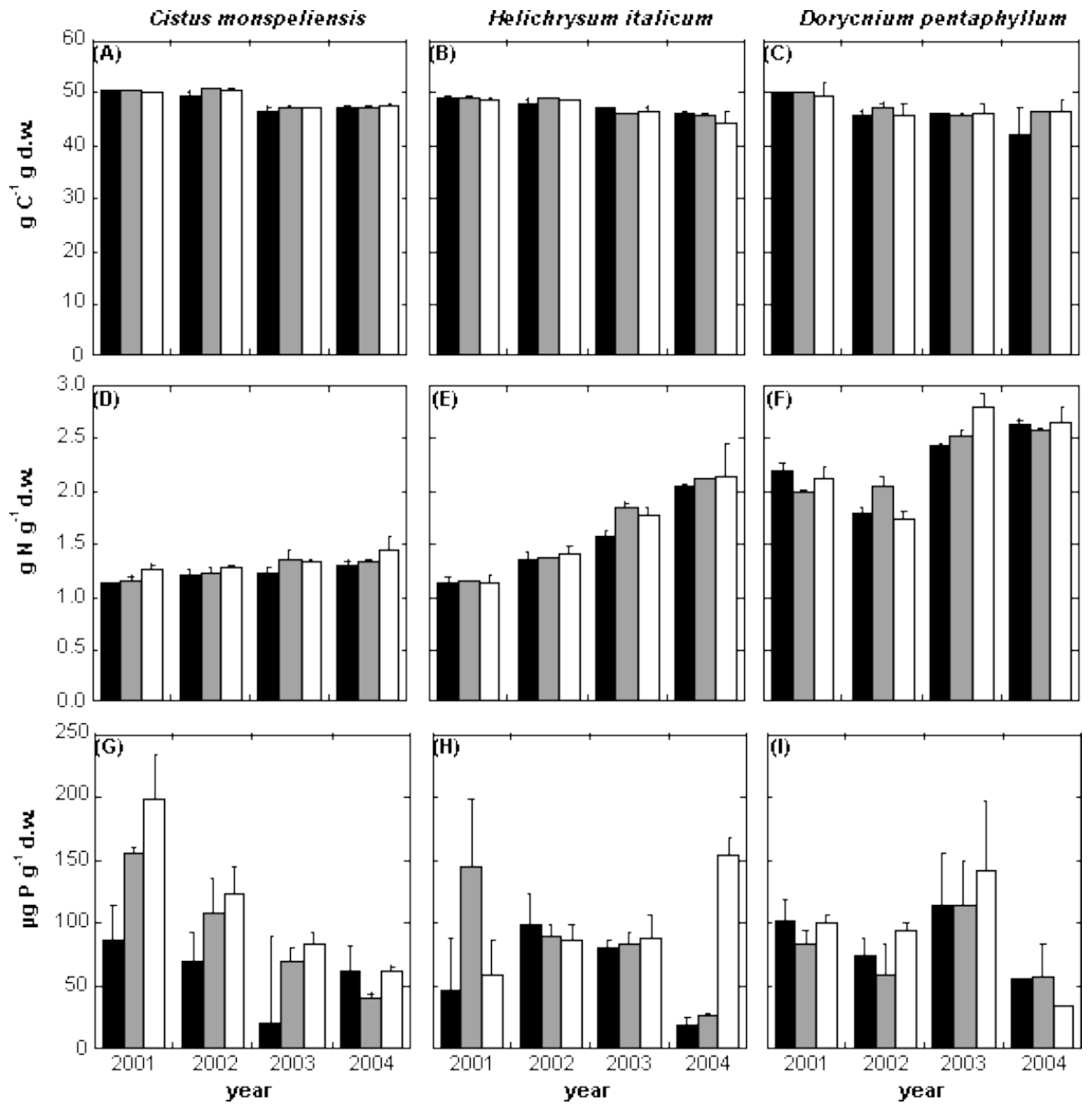

Fig. 6 - Leaf chemical composition (Carbon, Nitrogen and Phosphorous) of the three main species Cistus monspeliensis (a-d-g), Helichrysum italicum (b-e-h) and Dorycnium pentaphyllum (c-f-i) for the years 2001-2004 (2001 is pre-treatment). Control = Black bars; Warming $=$ Grey bars; Drought $=$ White bars.

significantly the leaf $\mathrm{C}$ content in all the species. During the study period, N concentration followed an increasing temporal trend in all the species.

$\mathrm{P}$ concentration varied among the species between 82 and $92 \mu \mathrm{g}$ per $\mathrm{g}$ of leaf dry weight (Fig. 6 g-h-i, Tab. 7). In Cistus there was a significant higher concentration of $\mathrm{P}$ in the drought than in the control (about $+60 \%$ ). The warming treatment did not alter significantly the leaf $\mathrm{P}$ content in all the species. Along the years, we observed a decreasing trend of leaf $\mathrm{P}$ concentration in Cistus but not in Helichrysum and Dorycnium, independently of the treatments.

In the three species the $\mathrm{C}: \mathrm{N}$ ratio followed a significant decreasing trend (Tab. 7), with a significant negative drought effect (about $-5 \%)$ on the average value in Cistus.

Nutrient concentration is the result of the balance between uptake and growth. The observed increase of $\mathrm{N}$ and $\mathrm{P}$ concentrations in the drought treatment in Cistus can be explained by the reduced shoot growth induced by the water shortage that we had observed in the same treatment. The absence of a concentration effect on the other two species could be the signal of the different behaviour with regard to a drier climate, and therefore could be a symptom of future change in species composition, as also partially seen in plant cover (Fig. 3).

It is worth to say that over time foliar $\mathrm{N}$ tended to increase and foliar $\mathrm{P}$ to decrease (although strictly to Cistus) in the control treatment (that is to say in natural conditions). The resulting increase in the N:P ratio highlights a progressive importance of $\mathrm{P}$ limitation (Peñuelas et al. 2004a, Sardans \& Peñuelas 2004), and this pattern could influence its evolution. On the other hand, a decrease in the $\mathrm{C}: \mathrm{N}$ ratio (more $\mathrm{N}$ available for decomposers) can lead to a better litter palatability and to a more rapid litter decomposition process (De Angelis et al. 2000), with positive consequences on nutrients' cycles. The observed reduced C:N in the drier conditions can be an alarm because, if a quicker decomposition is not accompanied by an increased uptake (as it is likely to occur given the decrease in plant cover in the drought treatment) nutrient leaching can strongly limit this ecosystem (Casermeiro et al. 2004, Martinez-Mena et al. 2002).

\section{Predawn water potential}

In the control treatment, predawn water potential (PWP) of Cistus shoots varied between -0.4 and $-3.5 \mathrm{MPa}$ (Fig. 7), similar to values found in another study investigating a different Cistus species (Borghetti et al. 2004). The lowest values occurred during summer period, except in October 2003, because of the dryness of that year. The warm-

Tab. 7 - F-ratios and p-values summary table of the ANOVAs on leaf chemical composition and $\mathrm{C} / \mathrm{N}$ ratios for the species C. monspeliensis, H. italicum and D. pentaphyllum.

\begin{tabular}{cllll}
\hline Element & \multicolumn{1}{c}{ Species } & \multicolumn{1}{c}{ Years } & \multicolumn{1}{c}{ Treatment } & Years*Treatment \\
\hline Carbon & C. monspeliensis & $\mathrm{F}=85.02 ; \mathrm{p}<0.001$ & $\mathrm{~F}=2.25 ; \mathrm{p}=0.13$ & $\mathrm{~F}=1.16 ; \mathrm{p}=0.36$ \\
& H. italicum & $\mathrm{F}=8.88 ; \mathrm{p}<0.01$ & $\mathrm{~F}=0.51 ; \mathrm{p}=0.61$ & $\mathrm{~F}=0.41 ; \mathrm{p}=0.86$ \\
& D. pentaphyllum & $\mathrm{F}=5.71 ; \mathrm{p}<0.01$ & $\mathrm{~F}=1.08 ; \mathrm{p}=0.36$ & $\mathrm{~F}=0.77 ; \mathrm{p}=0.60$ \\
Nitrogen & C. monspeliensis & $\mathrm{F}=7.80 ; \mathrm{p}<0.01$ & $\mathrm{~F}=5.82 ; \mathrm{p}<0.01$ & $\mathrm{~F}=0.67 ; \mathrm{p}=0.68$ \\
& H. italicum & $\mathrm{F}=33.10 ; \mathrm{p}<0.001$ & $\mathrm{~F}=0.63 ; \mathrm{p}=0.55$ & $\mathrm{~F}=0.24 ; \mathrm{p}=0.96$ \\
& D. pentaphyllum & $\mathrm{F}=83.49 ; \mathrm{p}<0.001$ & $\mathrm{~F}=0.87 ; \mathrm{p}=0.43$ & $\mathrm{~F}=4.33 ; \mathrm{p}<0.01$ \\
Phosphorous & C. monspeliensis & $\mathrm{F}=10.42 ; \mathrm{p}<0.001$ & $\mathrm{~F}=4.33 ; \mathrm{p}<0.05$ & $\mathrm{~F}=1.53 ; \mathrm{p}=0.22$ \\
& H. italicum & $\mathrm{F}=0.34 ; \mathrm{p}=0.79$ & $\mathrm{~F}=1.47 ; \mathrm{p}=0.26$ & $\mathrm{~F}=2.57 ; \mathrm{p}=0.06$ \\
& D. pentaphyllum & $\mathrm{F}=2.83 ; \mathrm{p}=0.07$ & $\mathrm{~F}=0.23 ; \mathrm{p}=0.80$ & $\mathrm{~F}=0.19 ; \mathrm{p}=0.98$ \\
C/N ratio & C. monspeliensis & $\mathrm{F}=24.62 ; \mathrm{p}<0.001$ & $\mathrm{~F}=5.98 ; \mathrm{p}=0.008$ & $\mathrm{~F}=0.78 ; \mathrm{p}=0.59$ \\
& H. italicum & $\mathrm{F}=60.7 ; \mathrm{p}<0.001$ & $\mathrm{~F}=0.61 ; \mathrm{p}=0.56$ & $\mathrm{~F}=0.30 ; \mathrm{p}=0.93$ \\
& D. pentaphyllum & $\mathrm{F}=45.79 ; \mathrm{p}<0.001$ & $\mathrm{~F}=0.57 ; \mathrm{p}=0.57$ & $\mathrm{~F}=1.95 ; \mathrm{p}=0.12$ \\
\hline
\end{tabular}


Fig. 7 - Comparison of: (a) control vs. warming drought predawn water shoots of Cistus monspeliensis in different dates. The symbol * indicates significant differences $(\mathrm{p}<0.05)$ among the treatments. Control $=$ full circle with continuous line; Warming $=$ full triangles with long dash line; Drought $=$ open squares with short dash. The darkened areas show the period with the drought treatment running. and (b) control vs. potentials measured on

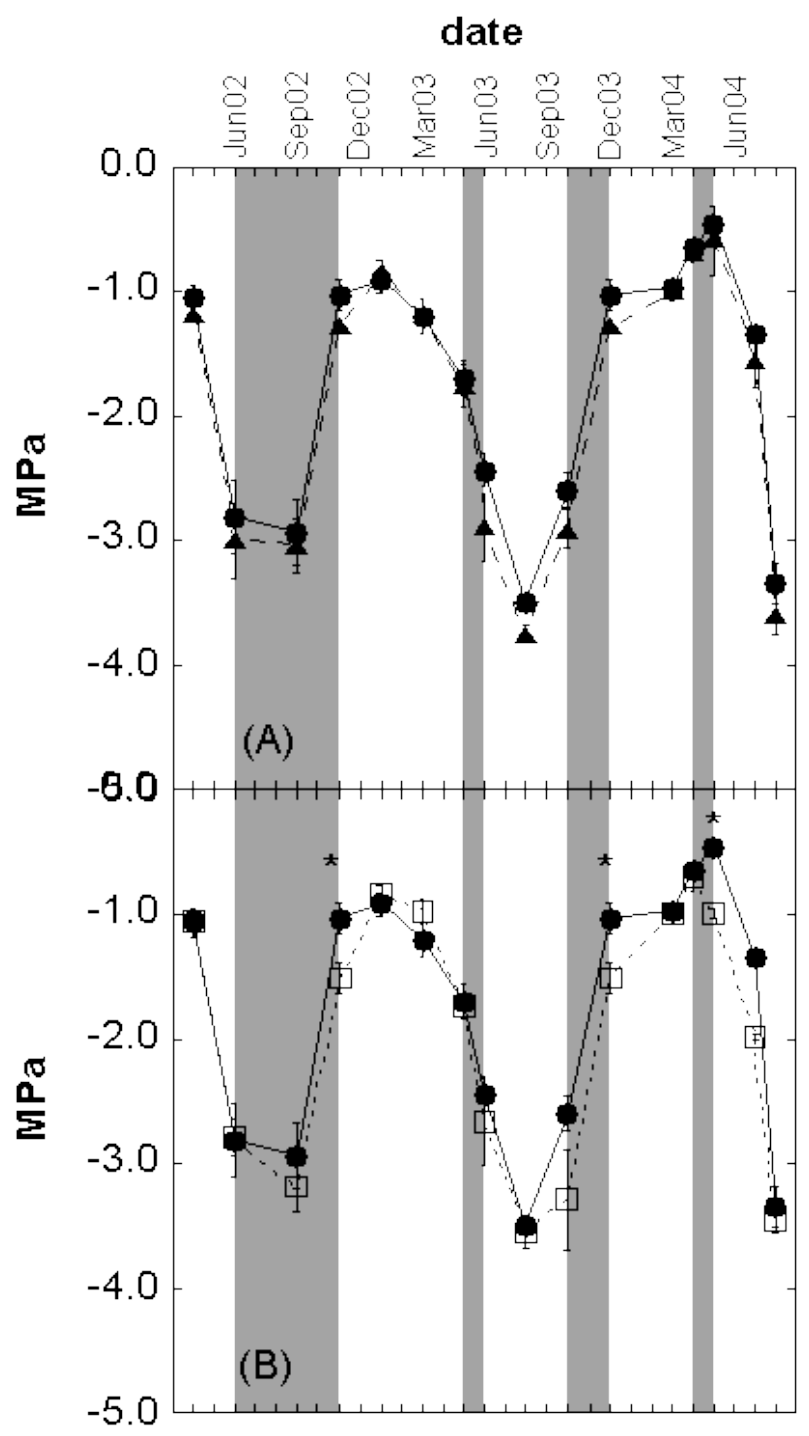

ing treatment did not affect the PWP. The warming treatment did not affected the PWP, showing a $-9 \%$ difference with the control, not statistically significant. The drought treatment negatively affected PWP at three sampling dates, when the drought treatment was running and during the season with enough precipitation, and not in the very dry spring 2003, when only about $50 \mathrm{~mm}$ of rain fell. On average, the percentage drought difference was $-11 \%$, not statistically significant from the control.

These results point out that Cistus is stressed under drier conditions and therefore it can perform less $\mathrm{C}$ accumulation and growth (Cinnirella et al. 2002, Abril \& Hanano 1998, Lebourgeois et al. 1998), as also confirmed by the decreased elongation of its shoots. The drought treatment decreased PWP in the short term (when the treatment was active), while this effect was absent during the rest of the year. Therefore, Cistus plants were able to recover after the removal of the stress factor. This character- istic is due to its shallow rooting depth and to the persistence of its over-summer leaves which allow it to re-establish its water potentials on the occasion of rain events occurring after the dry season (Werner et al. 1999, Harley et al. 1987).

\section{Conclusion}

Although not dramatically, the microclimate manipulation altered the microclimate according to common scenarios (Kundzewicz et al. 2001, Cubasch et al. 1996, Cubasch et al. 1995), giving a possible image of the climate in the short and medium term and the possible responses of this shrubland community.

The drought treatment influenced the changes of Cistus cover, differently from what happened to that of Helichrysum, in addition to the effects on shoot elongation in Cistus. This different behaviour could be the sign of a possible change in species composition with possible consequences on the evolution of this community. A new com- munity structure could imply different processes at soil (Hawkes et al. 2005) and plant level (Armas \& Pugnaire 2005). We underline the need of long term observation, because of the different responses of plants in the short- and long-term (Peñuelas et al. 2004a). The lack of a warming effect on the measured variables, could be the results of the low increase of temperature due to the manipulation, especially during the diurnal hours (Llorens et al. 2003) but stresses also the central role of water availability for plants of the Mediterranean region.

\section{Acknowledgments}

The research was funded by the EU under the project VULCAN (contract No. EVK2CT-2000-00094). We would like to thank Mr. Tullio Oro for the fieldwork when all the arrangements were installed; all the $\mathrm{PhD}$ students of the University of Sassari for the continuous monitoring of the area and a special thank to the Porto Conte staff.

\section{References}

Abril M, Hanano R (1998). Ecophysiological responses of three evergreen woody Mediterranean species to water stress. Acta Oecologica 19: 377 387.

Alegre J, Alonso-Blázquez $\mathrm{N}$, de Andrés EF, Tenorio JL, Ayerbe L (2004). Revegetation and reclamation of soils using wild leguminous shrubs in cold semiarid Mediterranean conditions: litterfall and carbon and nitrogen returns under two aridity regimes. Plant and Soil 263:203-212.

Allen SE (1974). Chemical analysis of ecological materials. Blackwell Scientific Publications.

Armas C, Pugnaire FI (2005). Plant interactions govern population dynamics in a semi-arid plant community. Journal of Ecology 93: 978-989.

Bakkenes M, Alkemade JRM, Ihle F, Leemans R, Latour JB (2002). Assessing effects of forecasted climate change on the diversity and distribution of European higher plants for 2050. Global Change Biology 8: 390-407.

Beier C, Emmett B, Gundersen P, Tietema A, Peñuelas J, Estiarte M, Gordon C, Gorissen A, Llorens L, Roda F, Williams D (2004). Novel Approaches to Study Climate Change Effects on Terrestrial Ecosystems in the Field - Drought and Passive Night Time Warming. Ecosystem 7: $583-$ 597.

Biondi E, Filigheddu R, Farris E (2001). Il paesaggio vegetale della Nurra (Sardegna nord-occidentale). Fitosociologia 38: 3-105.

Borghetti M, Magnani F, Fabrizio A, Saracino A (2004). Facing drought in a Mediterranean postfire community: tissue water relations in species with different life traits. Acta Oecologica 25: 6772.

Broncano MJ, Retana J, Rodrigo A (2005). Predicting the Recovery of Pinus halepensis and Quercus ilex Forests after a Large Wildfire in Northeastern Spain. Plant Ecology 180:47-56 Calvo L, Tárrega R, De Luis E (2002). The dy- 
namics of Mediterranean shrubs species over 12 years following perturbations. Plant Ecology 160: 25-42.

Carrión JS (2002). Patterns and processes of Late Quaternary environmental change in a montane region of southwestern Europe. Quaternary Science Reviews 21: 2047-2066.

Casermeiro MA, Molina JA, De La Cruz Caravaca MT, Hernando Costa J, Hernando Massanet MI, Moreno PS (2004). Influence of scrubs on runoff and sediment loss in soils of Mediterranean climate. Catena 57: 91-107.

Cesaraccio C, Pellizzaro G, Duce P, Spano D (2004). Analysis of phenological behaviour of some Mediterranean shrub species in responses to warming and drought conditions. $26^{\text {th }}$ Conference of Biometeorology and Agrobiology AMS 23-26 August 2004, Vancouver, British Columbia, Canada.

Cinnirella S, Magnani F, Saracino A, Borghetti M (2002). Response of a mature Pinus laricio plantation to a three-year restriction of water supply: structural and functional acclimation to drought Tree Physiology 22: 21-30.

Corrias B, Corrias DS, Valsecchi F (1983). Carta della vegetazione della Nurra di Alghero (Sardegna nord-occidentale). Collana Programma Finalizzato "Promozione Qualità Ambiente", AQ/1/229: 1-17. CNR, Roma.

Cubasch U, von Storch H, Waszkewitz J, Zorita E (1996). Estimates of climate change in Southern Europe derived from dynamical climate model output. Climate Research 7: 129-149.

Cubasch U, Waszkewitz J, Perlwitz J (1995). Regional climate changes as simulated in time-slice experiments. Climatic Change 31: 273-304.

De Angelis P, Chigwerewe KS, Scarascia Mugnozza GE (2000). Litter quality and decomposition in a $\mathrm{CO}_{2}$ - enriched Mediterranean forest ecosystem. Plant and Soil 224: 31-41.

De Angelis P, de Dato G, Spano D, Duce P, Sirca C, Asunis C, Pellizzaro G, Cesaraccio C, Sechi S, Scarascia Mugnozza G (2005). Una nuova area sperimentale di lungo termine, per lo studio degli effetti dell'incremento della temperatura e del periodo di aridità in formazioni di sclerofille mediterranee.Forests@2:37-51.

De Dato GD (2004). Effetti dei cambiamenti climatici sulla vegetazione arbustiva mediterranea: risultati della manipolazione ambientale nell'area sperimentale di Porto Conte (SS). Tesi di Dottorato in Ecologia Forestale. Università degli Studi della Tuscia, Viterbo.

De Luis M, Garcia-Cano MF, Cortina J, Raventos J, Gonzales-Hidalgo JC, Sanchez JR (2001). Climatic trends, disturbances and short-term vegetation dynamics in a Mediterranean shrubland. Forest Ecology and Management 147: 25-37.

Easterling DR, Horton B, Jones PD, Peterson TC, Karl TR, Parker DE, Salinger MJ, Razuvayev V, Plummer N, Jamason P, Folland CK (1997). Maximum and minimum temperature trends for the globe. Science 277: 364-367.

EEA (2004). Impacts of Europe's changing climate. An indicator based assessment. European Environment Agency Report No 2/2004.
Epstein H, E., Calef M, P., Walker M, D., Stuart Chapin F, Starfield A, M. (2004). Detecting changes in arctic tundra plant communities in response to warming over decadal time scales. Global Change Biology 108: 1325-1334.

Folland CK, Karl TR, Christy JR, Clarke RA, Gruza GV, Jouzel J, Mann ME, Oerlemans J, Salinger MJ, Wang S-W (2001). Observed climate variability and change. In: Climate Change 2001: The Scientific Basis. Contribution of Working Group I to the Third Assessment Report of the Intergovernmental Panel on Climate Change. (Houghton JT, Ding Y, Griggs DJ, Noguer M, van Der Liden PJ, Dai X, Maskell K, Johnson CA eds). Cambridge University Press, New York, pp. 99-182.

Giovannini G, Vallejo R, Lucchesi S, Bautista S, Ciompi S, Llovet J (2001). Effects of land use and eventual fire on soil erodibility in dry Mediterranean conditions. Forest Ecology and Managment 147: 15-23.

Gualdi S, Navarra A (2005). Scenari climatici nel bacino mediterraneo. Forest@ 2: 19-30.

Harley PC, Tenhunen JD, Beyschlag W, Lange OL (1987). Seasonal changes in net photosynthesis rates and photosynthetic capacity in leaves of Cistus salvifolius, a European Mediterranean semi-deciduous shrub. Oecologia 74: 380-388.

Harte J, Shaw R (1995). Shifting dominance within a montane vegetation community: results of a climate-warming experiment. Science 267: 876880 .

Hawkes CV, Wren IF, Herman DJ, Firestone MK (2005). On the separation of net ecosystem exchange into assimilation and ecosystem respiration: review and improved algorithm. Global Change Biology 11: 1424-1439.

Hollister RD, Webber PJ, Tweedie CE (2005). The response of Alaskan arctic tundra to experimental warming: differences between short- and long-term responses. Global Change Biology 11: 525-525.

Honnay O, Verhenyen K, Buraye J, Jacquemyn H, Bossuyt B, Hermy M (2002). Possible effects of habitat fragmentation and climate change on the range of forest plant species. Ecology Letters 5: 525-530.

Hughes L (2000). Biological consequences of global warming: is the signal already apparent? Trends in Ecology and Evolution 15: 56-61.

Körner C, Sarris D, Christodoulakis D (2005). Long-term increase in climatic dryness in the East-Mediterranean as evidenced for the island of Samos. Regional Environmental Change 5: 27-36.

Kundzewicz ZW, Parry ML, Cramer W, Holten JI, Kaczmarek Z, Martens P, Nicholls RJ, Öquist M, Rounsevell MDA, Szolgay J (2001). Europe. In: Climate Change 2001: Impacts, Adaptation, and Mitigation. Contribution of Working Group II to the Third Assessment Report of the Intergovernmental Panel on Climate Change. (Bullock PLHH, Hoffman MT, Rounsvell M, Seghal J, Várallyay G eds), Cambridge University Press, Cambridge, United Kingdom and New York, NY, USA, pp. 642-692.
Lavorel S, Canadell J, Rambal S, Terradas J (1998). Mediterranean terrestrial ecosystem: research priorities on global change effects. Global Ecology and Biogeography 7: 157-166.

Lebourgeois F, Lévy G, Aussenac G, Clerc B, Willm $F$ (1998). Influence of soil drying on leaf water potential, photosynthesis, stomatal conductance and growth in two black pine varieties. Annales des Sciences Forestières 55: 287-299.

Llorens L, Peñuelas J, Estiarte M (2003). Ecophysiological responses of two Mediterranean shrubs, Erica multiflora and Globularia alypum, to experimentally drier and warmer conditions. Physiologia plantarum 119: 231-243.

Martinez-Mena M, Rogel AJ, Castillo V, Albaladejo J (2002). Organic carbon and nitrogen losses influenced by vegetation removal in a semiarid mediterranean soil. Biogeochemistry 61: 309-321.

Merino O, Martin MP, Martin A, Merino J (1990). Successional and temporal changes in primary productivity in two Mediterranean scrub ecosystem. Acta Oecologica 11: 103-112.

Mossa L, Abbate G, Scoppola A (1993). Memoria illustrativa della carta della vegetazione della provincia di Cagliari. Annali di Botanica 49 suppl. 8: 1-57.

Netto AM, Pieritz RA, Gaudet JP (1999). Field study on the local variability of soil water content and solute concentration. Journal of Hydrology 215: 23-37.

Nijs I, Teughels H, Blum H, Hendrey G, Impens I (1996). Simulation of climate change with infrared heaters reduces the productivity of Lolium perenne L. in summer. Environmental and Experimental Botany 271-280.

Norby RJ, Edwards NT, Riggs JS, al. e (1997). Temperature controlled open-top chambers for global change research. Global Change Biology 3: 259-267.

Ogaya R, Peñuelas J (2003). Comparative field study of Quercus ilex and Phyllirea latifolia: photosynthetic response to experimental drought conditions. Environmental and Experimental Botany 50: 137-148.

Ogaya R, Peñuelas J, Martinez-Vilalta J, Mangiron M (2003). Effect of drought on diameter increment of Quercus ilex, Phillyrea latifolia, and Arbutus unedo in a holm oak forest of NE Spain. Forest Ecology and Management 180: 175-184.

Osborne CP, Mitchell PL, Sheehy JE, Woodward FI (2000). Modelling the recent historical impacts of atmospheric $\mathrm{CO}_{2}$ and climate change on Mediterranean vegetation. Global Change Biology 6: 445-458.

Pavón NP, Briones O, Flores-Rivas J (2005). Litterfall production and nitrogen content in an intertropical semi-arid Mexican scrub. Journal of Arid Environments 60: 1-13.

Peñuelas J, Filella I, Comas P (2002). Changed plant and animal life cycle from 1952 to 2000 in the Mediterranean region. Global Change Biology 8: 531-544.

Peñuelas $\mathrm{J}$, Gordon $\mathrm{C}$, Llorens L, Nielsen $\mathrm{T}$, Tietema A, Beier C, Bruna P, Emmett B, Estiarte 
M, Gorissen A, Williams D (2004a). Non-intrusive field experiments show different plant responses to warming and drought among sites, seasons and species in a North-South European gradient. Ecosystem 7: 598-612.

Peñuelas J, Filella I, Zhang X, Llorens L, Ogaya R, Lloret F, Comas P, Estiarte M, Terradas J (2004b). Complex spatiotemporal phenological shifts as a response to rainfall changes. New Phytologist 161: 837-846.

Pietracaprina A (1989). La Nurra, sintesi monografica. Gallizzi, Sassari.

Rovira P, Azcon-Bieto J, Fleck I, Vallejo VR (2002). Carbon sequestration in Mediterranean ecosystems: critical aspects related to plant respiration, wildfires and nitrogen budget. Contributions to Science 2: 467-482.

Rustad LE, Campbell JL, Marion GM, Norby RJ, Mitchell MJ, Hartley AE, Cornelissen JCH, Gurevitch J (2001). A meta-analysis of the response of soil respiration, net nitrogen mineralization, and aboveground plant growth to experimental ecosystem warming. Oecologia 126: 543 562.

Saavedra F, Inouye DW, Price MV, Harte J (2003). Changes in flowering and abundance of Delphinium nuttallianum (Ranunculaceae) in response to a subalpine climate warming experiment. Global Change Biology 9: 885-894.

Sardans J, Peñuelas J (2005). Drought decreases soil enzyme activity in a Mediterranean Quercus ilex L. forest. Soil Biology and Biochemistry 37: 455-461.
Sardans J, Peñuelas J (2004). Increasing drought decreases phosphorus availability in an evergreen Mediterranean forest. Plant and Soil 367-377.

Scarascia-Mugnozza G (2000). Forests of the Mediterranean region: gaps in knowledge and research needs. Forest Ecology and Managment 132: 97-109.

Shaver GR, Canadell J, Chapin III, F.S., Gurevitch J, Harte J, Henry G, Ineson P, Jonasson S, Melillo J, Rustad LE (2000). Global Warming and Terrestrial Ecosystem: a conceptual framework for analysis. BioScience 50: 871-882.

Simmons JA, Fernandez IJ, Briggs RD, Delaney MT (1996). Forest floor carbon pools and fluxes along a regional climate gradient in Maine, USA. Forest Ecology and Management 84: 81-95.

Skov F, Svenning J-C (2004). Potential impact of climatic change on the distribution of forest herbs in Europe. Ecogeography 27: 366-380.

Sternberg M, Shoshany M (2001). Influence of slope on Mediterranean woody formations: comparison of a semiarid and an arid site in Israel. Ecological Research 16: 335-345.

Strömgren M, Linder S (2002). Effects of nutrition and soil warming on stemwood production in a boreal Norway spruce stand. Global Change Biology 12: 1194-1204.

Tarrega R, Luis-Calabuig E, Alonso I (1997). Space-time heterogeneity in the recovery after experimental burning and cutting in a Cistus laurifolius shrubland. Plant Ecology 129: 179187.

Tarrega R, Luis-Calabuig E, Valbuena L (2001).
Eleven years of recovery dynamic after burning and cutting in two Cistus communities. Acta Oecologica 22: 277-283.

Troumbis AY, Memtsas D (2000). Observational evidence that diversity may increase productivity in Mediterranean shrublands. Oecologia 125: 101-108.

Turnbull MH, Murthy R, Griffin KL (2002). The relative impacts of daytime and night-time warming on photosynthetic capacity in Populus deltoides. Plant, Cell and Environment 25: 17291737.

USDA (1993). Soil Survey Manual. United States Department of Agriculture Handbook No. 18, US Department of Agriculture.

Usó JL, Mateu J, Karjalainen T, Salvador P (1997). Allometric regression equations to determine aerial biomasses of Mediterranean shrubs. Plant Ecology 132: 59-69.

Valsecchi F (1976). Sui principali aspetti della vegetazione costiera della Nurra Nord-occidentale (Sardegna settentrionale). Giornale Botanico Italiano 110: 21-63.

Wan S, Luo Y, Wallace L (2002). Changes in microclimate induced by experimental warming and clipping in tall grass prairie. Global Change Biology 8: 754-768.

Werner C, Correia O, Beyschlag W (1999). Two different strategies of Mediterranean macchia plants to avoid photoinibitory damage by excessive radiation levels during summer drought. Acta Oecologica 20: 15-23. 